\title{
ANALYSIS OF WATER QUALITY USING PHYSICO-CHEMICAL PARAMETERS \\ CHHATRI TALAO TANK IN AMRAVATI DISTRICT, MAHARASHTRA,INDIA
}

\author{
1S. Doifode, ${ }^{2}$ S. Rewatkar , ${ }^{3}$ S. Goswami \\ ${ }^{1}$ HOD Dept. of Chemistry ,Govt. College of Engg. , Amravati \\ 2Principal Mohsinbhai Zaweri college Desaiganj, Gadchiroli \\ 3Research Student
}

\begin{abstract}
:
The paper deals with the physico chemical parameter of the Chhatri Talao Tank in Amravati District, Maharashtra, India. Monthly changes in physical and chemical parameters such as water temperature, turbidity, total dissolved solids, PH , dissolved oxygen, free carbon dioxide and total hardness, chlorides, alkalinity were analyzed for the periods of one year from the $1^{\text {st }}$ January 2012 to $31^{\text {st }}$ December 2012. All parameters were exides the permissible limit. The results indicate that the tank is polluted and cannot be used for the domestic purposes.
\end{abstract}

KEYWORDS: Physico-Chemical Parameter, Monthly Variation, drinking water.

\section{INTRODUCTION:}

The tank occupy vital role in to local ecosystem as well as used for domestic purposes. As water is one of the most important compounds of the ecosystem, but due to increased human population, industrialisation, use of the fertilizers in the agriculture and manmade activity. The natural aquatic resources are causing heavy and varied pollution in aquatic environment leading to pollute water quality and depletion of aquatic biota.It is therefore necessary that the quality of drinking water should be checked at regular time of interval, because due to use of contaminated drinking water, human population suffers from varied of water diseases.

The present study involves the analysis of water described by the the physical water quality in terms of physico chemical parameters of Chhatri Talao, Amravati District, Maharashtra, India. This tank is basically for the fisheries and partially domestic activities. In old days, it was used for the drinking purposes. 


\section{MATERIAL AND METHODS:}

The water sample from Chhatri Talao were collected from the two different border in the morning hours between 10 to11am in the in polythene bottle regularly for every month. The water samples were immediately brought in the laboratory for the estimation of various physico chemical parameters like water temperature and $\mathrm{PH}$ were recorded at time of sample collection by using the thermometer and digital PH meter. While other parameters such as DO, TDS, free $\mathrm{CO}_{2}$, hardness, alkalinity, chloride were estimated in the laboratory by using Indian Standard Procedure( litration method)

\section{RESULT AND DISCUSSION:}

\begin{tabular}{|c|c|c|c|c|}
\hline Month & $\begin{array}{c}\text { Temp } \\
(\mathbf{o C})\end{array}$ & $\begin{array}{c}\text { Turbidity } \\
\text { (NTU) }\end{array}$ & $\begin{array}{c}\text { TDS } \\
\text { (mg/lit) }\end{array}$ & PH \\
\hline January & 22 & 30.9 & 610 & 7.65 \\
\hline February & 23 & 30.7 & 620 & 7.06 \\
\hline March & 23 & 30.8 & 640 & 7.33 \\
\hline April & 23 & 29.7 & 690 & 7.85 \\
\hline May & 25 & 29.6 & 600 & 7.65 \\
\hline June & 24 & 33.9 & 770 & 7.75 \\
\hline July & 23 & 32.6 & 680 & 7.55 \\
\hline August & 24 & 33.2 & 680 & 7.45 \\
\hline September & 23 & 31.1 & 680 & 7.15 \\
\hline October & 22 & 30.9 & 690 & 7.05 \\
\hline November & 20 & 30.7 & 620 & 7.45 \\
\hline December & 22 & 30.7 & 610 & 7.35 \\
\hline
\end{tabular}

Table1: Physical parameters Of Chhatri Talao Tank

a) Climate: There is a rapid increase in temperature after the month of January, May is the hottest month. The climate of the year in this is divided into three seasons viz. hot season from the February to May, monsoon from June to September and winter from November to January.

b) Water temperature: Generally, the weather is quite cool, however the water temperature plays an important factor which influences the chemical, bio-chemical characteristic of water body. The maximum temp of $29^{\circ} \mathrm{C}$ was recorded in May and minimum of $20^{\circ} \mathrm{C}$ was recorded in month of December in year of 2012.The temperature in summer was high due to low water level, high temperature and clear atmosphere. 


\begin{tabular}{|c|c|c|c|c|c|}
\hline Month & $\begin{array}{c}\text { Free } \\
\mathbf{C O}_{\mathbf{2}}\end{array}$ & $\begin{array}{c}\text { Dissolved } \\
\mathbf{O}_{\mathbf{2}} \\
\text { (mg/lit) }\end{array}$ & $\begin{array}{c}\text { Total } \\
\text { Hardness } \\
\text { (mg/lit) }\end{array}$ & $\begin{array}{c}\text { Alkalinity } \\
\text { (mg/lit) }\end{array}$ & $\begin{array}{c}\text { Chloride } \\
\text { (mg/lit) }\end{array}$ \\
\hline January & 0.7 & 9.6 & 88 & 118 & 22.00 \\
\hline February & 0.5 & 9.00 & 95 & 120 & 26.0 \\
\hline March & 0.8 & 12.00 & 98 & 125 & 30.5 \\
\hline April & 3.7 & 14.00 & 120 & 128 & 30.5 \\
\hline May & 7.5 & 16.00 & 140 & 165 & 32.5 \\
\hline June & 8.1 & 14.25 & 130 & 130 & 34 \\
\hline July & 4.4 & 9.30 & 105 & 120 & 27 \\
\hline August & 16.7 & 8.30 & 89 & 140 & 29.8 \\
\hline September & 10.8 & 8.00 & 7.60 & 150 & 23 \\
\hline October & 14.2 & 7.65 & 88 & 120 & 22 \\
\hline November & 16.5 & 8.3 & 90 & 129 & 25 \\
\hline December & 16.9 & 7.62 & 79 & 133 & 27 \\
\hline
\end{tabular}

Table 2: Chemical Parameters Of Chhatri Talao Tank

c) Turbidity: The turbidity of water fluctuate from the $30.9 \mathrm{NTU}$ to 33.9

NTU. Turbidity is very high due to human activities and suspended particulate matter.

d) Total Dissolved Solids: The total dissolved solids fluctuate from the $600 \mathrm{mg} / \mathrm{lit}$ to $770 \mathrm{mg} / \mathrm{lit}$. The maximum value is $770 \mathrm{mg} /$ lit recorded in month of June due to heavy rainfall and minimum is $600 \mathrm{mg} / \mathrm{lit}$ in the month of May.

e) $\mathbf{p H}$ : $\mathrm{pH}$ was alkaline values ranges from 7.05 to 7.85 . The maximum $\mathrm{PH}$ value was recorded in the month of the April and minimum 7.05 in the month of October. Most of the bio chemical and chemical reactions are influenced by the $\mathrm{PH}$.

f) Dissolved $\mathbf{O}_{2}:$ The value of the DO fluctuate from $7.65 \mathrm{mg} /$ lit to 16 $\mathrm{mg} / \mathrm{lit}$. The maximum value $16 \mathrm{mg} / \mathrm{lit}$ was recorded in The month of the May and minimum value 7.65 in the month of the November. The high DO in summer is due to increase in the temperature and duration of sunlight has influenced on the of soluble gases $\mathrm{O}_{2}$ and $\mathrm{CO}_{2}$.

g) Free $\mathbf{C O}_{2}$ : This value of free $\mathrm{CO}_{2}$ ranges from 0.5 to $16.9 \mathrm{mg} / \mathrm{lit}$. The maximum value was recorded in the month of the December and minimum value $0.5 \mathrm{mg} /$ lit in the February. This may be depends upon alkalinity and hardness of water body. The $\mathrm{CO}_{2}$ was high in December 
which is related to the high rate of decomposition in the warmer month.

h) Hardness: The hardness fluctuate from 79 to $140 \mathrm{mg} / \mathrm{lit}$. The maximum value $140 \mathrm{mg} / \mathrm{lit}$ was recorded in the month of the May and minimum $79 \mathrm{mg} /$ lit in the month of October. High value of hardness during summer is due to decrease in water level and increase of rate of evaporation of water .

i) Alkalinity: Total alkalinity ranges from the 118 to $165 \mathrm{mg} / \mathrm{lit}$. The maximum value $165 \mathrm{mg} /$ lit was recorded in the month of May and minimum 18 in the month of the January. The alkalinity was maximum in the may due to the increase in the bicarbonate in the water and minimum in winter due to high photosynthesis rate.

j) Chloride: The value of chlorides ranges from $22 \mathrm{mg} /$ lit to $32.5 \mathrm{mg} / \mathrm{lit}$. The maximum value $32.5 \mathrm{mg} /$ lit was recorded in the month of May and minimum in the month of January.

\section{REFERENCES}

Abbasi, S.A.; F.I. Khan; K.Sentivelani and A.Shabuden (1999): Indian EnvironHLTH,Vol.41(3),pp. 176-183

Abraham susheela (1980): Ecology of vellayani lake fish fauna and physico chemical condition . Indian J. Ecology 7(1): 119-127.

Ahea (1993): water microbiology Expt.in microbiology ,plant pathology and

Tissue culture, Vishwa prakashan,New Delhi,pp.299-314.

Bondre(2006):"Analysis of waste water from M.I.D.C. area of Amravati”.

Dissertation of Enviromental science Department, Amravati University, Amravati.

Dr.Singh (2002): Water manegment in rural and urban area ,Agrotech Publishing Academy, Udaipur

Nandy and Deo(1960):Lonar Lake , A case for protection and conservation as Ramser site by R.A. Malu ,Nation conference on wetland conservation pp13-18

Ochieng :E.Z.(2008)Water quality and trace metal distribution in a pristine Lake in the lake basin in Kenya.Bull. Environ.Contam .ToxicolVol.(80) 363-368.

Patalvanshi,A.R.(2010-2011)Dissertation of Environmental Science Department1,Amravati(S.G.B.A.) University ,Amravati. 